\title{
SISTEM PAKAR PENDETEKSI PENYAKIT PADA TANAMAN PADI MENGUNAKAN METODE (FORWARD CHAINING) BERBASIS WEB DI DESA SUBAIM KECAMATAN WASILE
}

\author{
EXPERT DISEASE DETECTION SYSTEM IN RICE PLANTS USING \\ FORWARD CHAINING METHOD WEB-BASED IN SUBAIM VILLAGE, \\ WASILE DISTRICT
}

\author{
M. Hairil Alle ${ }^{1}$, Rusmin Ansar ${ }^{2}$, Hairil Kurniadi Sirajuddin ${ }^{3}$, Muharto $^{4}$ \\ Program Studi Manajemen Informatika \\ Politeknik Sains \& Teknologi Wiratama Maluku Utara \\ hairilalle@gmail.com
}

\begin{abstract}
Abstrak
Jenis padi dalam penelitian ini adalah padi basah atau padi sawah dinamakan padi Santana, yang dibudidaya didesa subaim, namun sering dijumpai berbagai macam penyakit yang menyerang pada tamanan padi ini, penyakit tersebut dapat diketahui dari gejala-gejala yang ditimbulkanya. Dalam penelitian ini terdapat beberapa jenis dan gejala penyakit yaitu, Hawar daun, Kerdil Blas, Tungro, dan Busuk Batang. Ada 5 jenis penyakit dan 21 gejala, akan tetapi untuk mengetahui secara tepat jenis penyakit yang menyerang padi tersebut memerlukan seorang pakar/ahli pertanian, sedangkan jumlah pakar pertanian terbatas dan tidak dapat mengatasi permasalahan petani dalam waktu yang bersamaan, sehingga diperlukan suatu sistem yang mempunyai kemampuan seperti seorang pakar, yang mana di dalam sistem ini berbasis pengetahuan keahlian seseorang pakar pertanian mengenai penyakit dan gejala tanaman padi. Pada penelitian ini dirancang sistem pakar pendeteksi penyakit pada tanaman padi menggunakan metode forward chaining dengan gambar berbasis website, yang maksudkan untuk membantu petani dalam mendeteksi penyakit pada tanaman padi. Sehingga dapat memberikan solusi serta saran penanganannya. Dengan adanya aplikasi ini dapat membantu petani mendiagnosa penyakit tanaman padi secara digital sehingga informasi maupun solusi yang dihasilkan sesuai dengan seseorang ahli pakar pertanian

Kata kunci: Sistem pakar, Metode Forward Chaining, Berbasis Website,

Abstract

In this study, rice is wet rice or lowland rice called Santana rice, which is cultivated in the village of Subaim, but there are often various kinds of diseases that attack this rice plant. The condition can be seen from the symptoms it causes. In this study, there are several types and symptoms of the disease: Blight, Dwarf Blas,
\end{abstract}


Tungro, and Stumps. There are five types of conditions and 21 signs, but to find out exactly the types of diseases that attack rice requires an Expert / agricultural expert, while the number of farming experts is limited and cannot solve farmer problems simultaneously, a system with the ability is needed like an expert, based on the knowledge of an agricultural expert's expertise regarding rice plant diseases and symptoms. In this study, an expert system for detecting rice diseases using the forward chaining method with web-based. Designed to help farmers see rice plants' conditions to provide solutions and suggestions for handling. With this application, it can help farmers diagnose rice plant diseases digitally so that the information and solutions produced are by an agricultural expert

\section{Keyword: Expert system, Forward Chaining Method, Website Based}

\section{PENDAHULUAN}

Pertanian mempunyai arti yang penting bagi kehidupan manusia, selama manusia hidup, selama itu juga pertanian akan tetap ada. Hal itu disebabkan karena makanan merupakan kebutuhan manusia paling pokok selain udara dan air. Makanan merupakan hasil dari pertanian yang mana setiap tahun kebutuhan akan makanan semakin meningkat karena populasi manusia terus bertambah. Secara khusus beras merupakan hasil dari tanaman padi yang digunakan sebagai makanan pokok manusia (Setiawan, 2016).

Hal yang sering terjadi, banyak kerugian yang diakibatkan karena adanya penyakit tanaman yang terlambat untuk mendeteksi. Ketika sudah mencapai tahap yang parah, maka menyebabkan terjadinya gagal panen. Sebenarnya setiap penyakit tanaman tersebut sebelum mencapai tahap yang lebih parah, tidak ada penanganan dan tindakan secara serius oleh petani padi tersebut, pada umumnya penyakit padi hanya menunjukkan gejala-gejala penyakit yang diderita masih dalam tahap yang ringan dan masih sedikit sehingga petani sering mengabaikannya, hal ini karena ketidaktahuannya dan menganggap gejala tersebut sudah biasa terjadi pada masa tanam, sampai suatu saat timbul gejala yang sangat parah dan meluas, sehingga sudah terlambat untuk dikendalikan. Maka seorang ahli/pakar pertanian dalam hal ini mempunyai kemampuan untuk menganalisa gejala-gejala penyakit tanaman tersebut, tetapi untuk mengatasi semua persoalan yang dihadapi petani terkendala oleh waktu dan jarak karena banyaknya petani yang mempunyai masalah dengan tanamannya.

Menurut Pegawai Penyuluhan Pertanian Lapangan (BPP) Kecamatan Wasile bahwa, di Daerah Subaim sebagian besar masyarakatnya berprofesi sebagai petani khususnya petani tamanan padi dan memliki luas tani mencakup 1.331, Hektar. Namun 
petugas atau seorang Ahli dan pakar pertanian terkendala oleh waktu dan jarak karena banyaknya petani yang mempunyai masalah dengan tanamannya. Berdasarkan uraian masalah sebelumya maka diusulkan Aplikasi Pendeteksi Penyakit Tanaman Padi menggunakan Metode Forward Chaining Berbasis Website Di desa Subaim Kecamatan Wasile.

\section{Rumusan Masalah}

$\begin{aligned} & \text { Berdasarkan latar belakang } \\ & \text { dapat } \\ & \text { sebelumnya } \\ & \text { diidentifikasikan }\end{aligned}$ permasalahan yang
diambil sebagai topik dari penelitian
ini adalah bagaimana merancang
aplikasi Sistem Pakar Pendeteksi
Penyakit Pada Tanaman Padi
Mengunakan Metode (Forward
Chaining Berbasis Web di Desa
Subaim Kecamtan Wasile?

\section{LANDASAN TEORI}

\section{Pengertian Sistem}

Sistem adalah kumpulan orang yang saling berkerja sama dengan ketentuan-ketentuan aturan yang sistematis dan terstruktur untuk membentuk suatu kesatuan yang melaksanakan suatu fungsi untuk mencapai tujuan. Sistem memiliki beberapa kareteristik atau sifat yang terdiri dari komponen sistem, batasan sistem, lingkungan luar sistem, penghubung sistem, masukan sistem, keluaran sistem, pengolahan sistem dan sasaran sistem (Anggraeni,2017).

\section{Pengertian Pakar}

Pakar adalah seseorang yang mempunyai, pengetahuan, pengalaman, dan metode khusus, serta mampu menerapkan untuk mencegah masalah atau memberi nasehat. Seorang pakar harus mampu menjelaskan dan mempelajari hal - hal yang erkaitan dengan topic permasalan, jika perlu harus mapu menyusun kembali pengetahuan pengetahuan yang di dapatkan dan dapat mencegahkan aturan - aturan serta menentukan relevansi kepakaranya. (Sutujo, 2011).

\section{Sistem Pakar}

Sistem pakar (Expert Sistem) adalah sistem yang berusaha mengadopsi pola piker manusia untuk selanjutnya di implementasikan dalam sebuah perangkat lunak, agar komputer dapat menyelesaiakan masalah seperti yang biasa dilakukan oleh para ahli. (Djoge, 2018).

\section{Forward Chaining}

Forward Chaining adalah teknik pencarian yang demulai dengan fakta yang diketahui, kemudian mencocokan fakta-fakta tersebut dengan bagian $I F$ dari rules IF_THEN. Bila ada fakta yang cocok dengan bagian $I F$. Maka Rule tersebut dieksekusi. Bila sebuah 
Rule dieksekusi, maka sebuah fakta baru (Bagian THEN) Ditambahkan ke dalam database. Setiap Rule hanya boleh dieksekusi sekali saja (Setojo,2010).

\section{Penerapan Forward Chaining}

Dalam sistem pakar ini teknik inferensi yang digunakan adalah pelacakan dan pencarian. Teknik ini menegunakan metode (forward chaining) yaitu dimulai dari premispremis informasi masukan (if) kemudian menuju konklusi atau driven information (then).

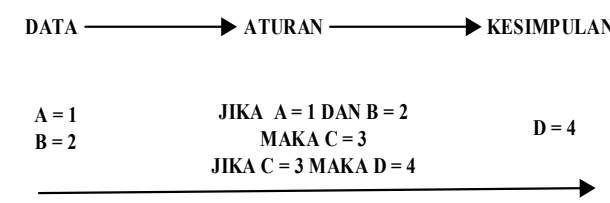

Gambar 1. Penerapan Forward

\section{Chaining}

\section{Tanaman Padi}

Tanaman padi merupakan salah satu jenis tanaman rerumputan. Tanaman padi termasuk ke dalam genus Oryza L. yang terdiri dari kurang lebih 25 spesies yang tersebar di daerah tropik dan subtropik seperti Asia, Afrika, Amerika dan Australia. Adapun tanaman padi memiliki bermacam-macam jenis penyakit yang dapat menyebabkan kerugian, kehilangan hasil panen yang tinggi dan berpengaruh terhadap sasaran produksi. Untuk dapat menekan timbulnya penyakit tanaman padi diperlukan upaya pengendalian. Penyakit tanaman merupakan hasil interaksi antara tiga faktor yaitu pathogen (jamur, bakteri dan virus), tanaman padi ini sangat rentan dalam faktor lingkungan yang tidak baik.

\section{Pertanian Wasile}

Lahan sawah adalah lahan pertanian yang berpetak-petak dan dibatasi oleh pematang (galengan), saluran untuk menahan/menyalurkan air, yang biasanya ditanami padi sawah tanpa memandang dari mana diperoleh atau status lahan tersebut. Lahan yang dimaksud termasuk lahan yang terdaftar di Pajak Bumi Bangunan, Iuran Pembangunan Daerah, lahan bengkok, lahan serobotan, lahan rawa yang ditanami padi dan lahan bekas tanaman tahunan yang telah dijadikan sawah, baik yang ditanami padi, palawija atau tanaman semusim lainnya (Stastik Kabupaten Halmahera Timur).

\section{Pengertian Website}

Website adalah kumpulan dari halaman web yang sudah dipublikasikan di jaringan internet dan memiliki dominal/URL (Uniform Resource Locator) yang dapat diakses semua pennguna internet dengan cara mengetikan alamatnya (Arief dalam Nofyat, 2018)

\section{Pengertian MySQL}


MySQL adalah sebuah database management sistem (manajemen basis data) mengunakan perintah dasar $S Q L$ (Structured Query Languange) yang cukup terkenal. Database management sistem (DBMS) MySQL multi penguna dan multi alur ini sudah dipakai lebih dari 6 juta penguna di seluruh dunia. MySQL adalah DBMS yang open Source dengan dua bentuklisensi, yaitu Free Software (perangkat lunak bebas) dan Shareware( perarangkat lunak berpemilik yang pengunanya terbatas). Jadi MySQL adalah database Server yang gratis dengan lisensi GNU, GPL (General Publik License) sehingga dapat anda pakai untuk keperluan pribadi atau kumersil tanpa harus membayar lisensi yang ada (Yusril dan Kawan-kawan, 2019).

\section{METODE PENELITIAN}

\section{Lokasi dan Waktu Penilitian}

1. Lokasi peneliatian ini dilaksanakan berlokasi di desa Subaim, Kecamatan Wasile Kabupaten Halmahera Timur.

2. Waktu penelitian ini berlangsung selama 4 bulan, mulai dari bulan September sampai dengan bulan Desember 2020

\section{Jenis dan Sumber Data}

Penelitian ini menggunakan dua jenis data yaitu: data primer dan data sekunder. a. Data primer merupakan data yang diperoleh langsung dari petani padi terhadap factor penyakit padi melalui observasi dan wawancara.

b. Data Sekunder merupakan data yang di peroleh dari dokumendokumen yang berupa data/informasi melalui buku-buku dan media internet sebagai pendukung reverensi yang berhubungan dengan objek penelitian.

\section{Metode Pengumpulan Data}

Metode pengumpulan data merupakan cara yang digunakan peneliti untuk mendapatkan data dalam suatu penelitian dimana metode pengumpulan data yang digunakan dalam penelitian ini diperoleh melalui opservasi, wawancara, dokumentasi:

1. Observasi

Merupakan metode pengumpulan data yang dilakukan lewat pengamatan lansung ke lapangan sehingga sumber data yang diperoleh sesuai dengan kebutuhan penelitian tentang penyakit padi.

2. Wawancara

Merupakan metode pengumpulan data yang dilakukan melalui tatap muka dan tanya jawab antara peneliti dan narasumber agar data yang diperoleh benar-benar akurat sehingga tidak ada manipulasi data yang terdapat pada objek penelitian

3. Dokumentasi 
Merupakan metode pengumpulan data yang di peroleh dari dokumen-dokumen yang berisi data atau informasi serta pengetahuan dalam bentuk gambar/foto, yang berkaitan dengan penyakit padi.

\section{Metode pengembangan Sistem}

\section{Waterfall Modeling}

Waterfall atau metode air terjun sering dinamakan siklus hidup klasik (classic life cycle), dimana hal ini menggambarkan pendekatan yang sistematis dan juga berurutan pada pengembangan perangkat lunak, dimulai dengan spesifikasi kebutuhan pengguna lalu berlanjut melalui tahapan-tahapan perencanaan (plening), permodelan (medeling), kontruksi (construction), serta penyerahan system ke para pelanggan/pengguna (deployment), yang diakhiri dengan dukungan pada perangkat lunak lengkap yang dihasilkan (Pressman dalam Muhammad dkk 2019).

Tahapan-tahapan yang terdapat dalam Waterfall dapat dilihat pada gambar sebagai berikut:

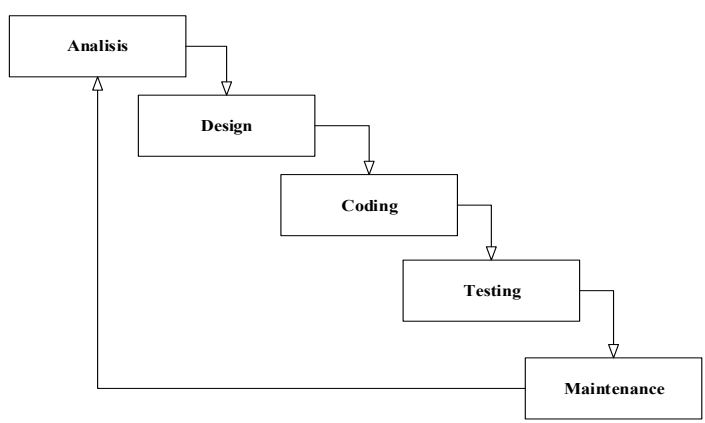

Gambar 2. Model Air Terjun Wterfall

\section{Kebutuhan Fungsional}

Kebutuhan fungsional adalah kebutuhan - kebutuhan yang memiliki keterkaitan langsung dengan sistem. Kebutuhan fungsional dari sistem ini adalah

1. Kebutuhan Penguna

a. Mendapatkan Informasi tentang penyakit pada tanaman padi serta cara mengatasi masalah yang ditemui sehingga mendapat solusi penangananya

b. Mengetahui jenis-jenis penyakit yang dialami oleh tanaman padi

2. Kebutuha Administrator

a. Melakukan login ke Sistem

b. Mengelolah data pendeteksi penyakit

\section{Kebutuhan Non-Fungsional}

Kebutuhan

Non-fungsional adalah kebutuhan yang tidak secara langsung terkait dengan fitur tertentu di dalam sistem, antara lain sebagai berikut :

1. Kebutuhan Perangkat Lunak 
a. Sistem Operasi windows 8.1 Pro, System Type 64-Bit

b. MysQL sebagai media database

c. Microsoft office word 2010 Sebagai pembuatan hasil laporan

d. Microsoft Visio 2016 untuk membuat gambar alur program.

e. Notepad++ digunakan untuk editor dalam merancang bahasa pemrograman website.

f. Xampp Untuk Media Server.

g. Pemograman menggunakan bahasa HTML, PHP, CSS, dan MySQL

2. Kebutuhan Perangkat Keras

a. Laptop Lenovo G40-30,Intel $\AA$ CPU N2940@1.83GHz, 4.00 GB (3.89 GB usable)

b. Printer Canon iP2770 untuk mecetak Hasil Peneltian

\section{Alur Peneitian}

Alur penelitian merupakan urutan langkah-langkah tahapan penelitian yang akan dilakukan, berikut ini adalah gambar langkah urutan alur penilitian.

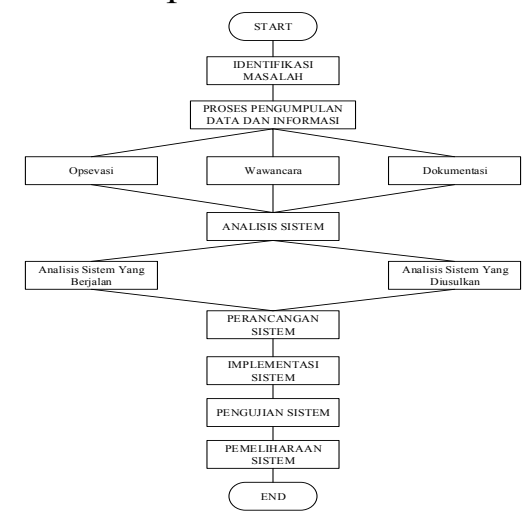

Gambar 3. Alur penelitian

\section{ANALISIS DAN PERANCANGAN Analisis Sistem yang berjalan}

Sistem yang berjalan merupakan rancangan hasil analisa sistem yang digunakan pada pertanian padi di Desa Subaim Kecamatan Wasile.

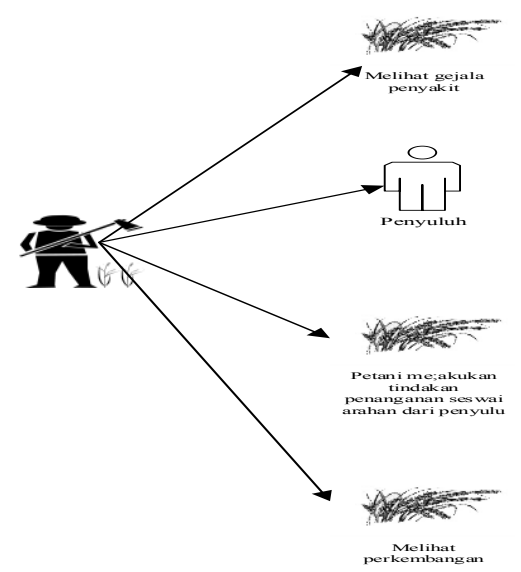

Gambar 4. Visual sistem yang berjalan

\section{Analisis Sistem yang diusulkan}

Berdasarkan sistem yang berjalan maka peneliti mengusulkan sistem yang baru, berikut perancangan $U M L$ (Use Case Diagram).

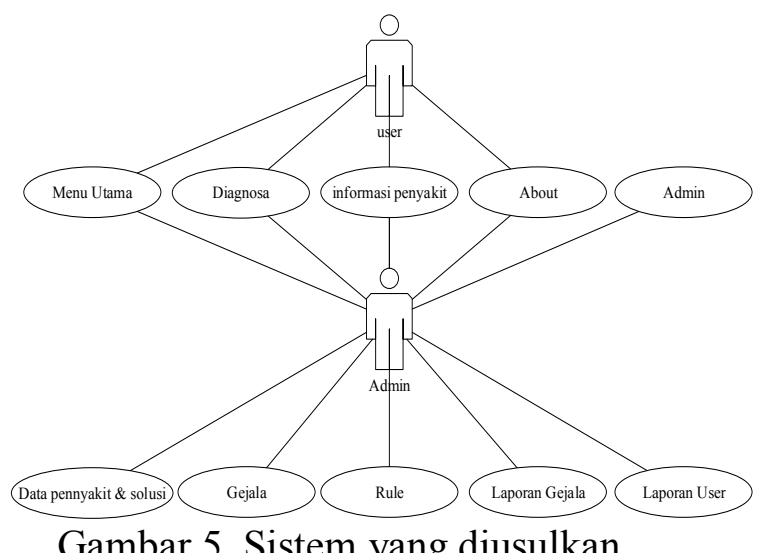

Gambar 5. Sistem yang diusulkan 


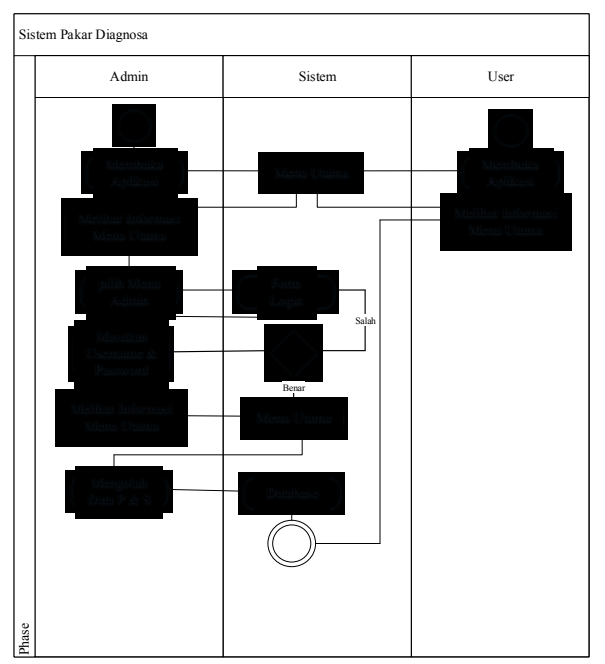

Gambar 6. Aktivity Menu Utama

\section{Class Diagram}

Diagram Class adalah diagram $U M L$ yang mengambarkan kelas-kelas dalam sebah sistem dan hubungan antara satu dengan yang lain, serta dimasukkan pula atribut dan operasi.
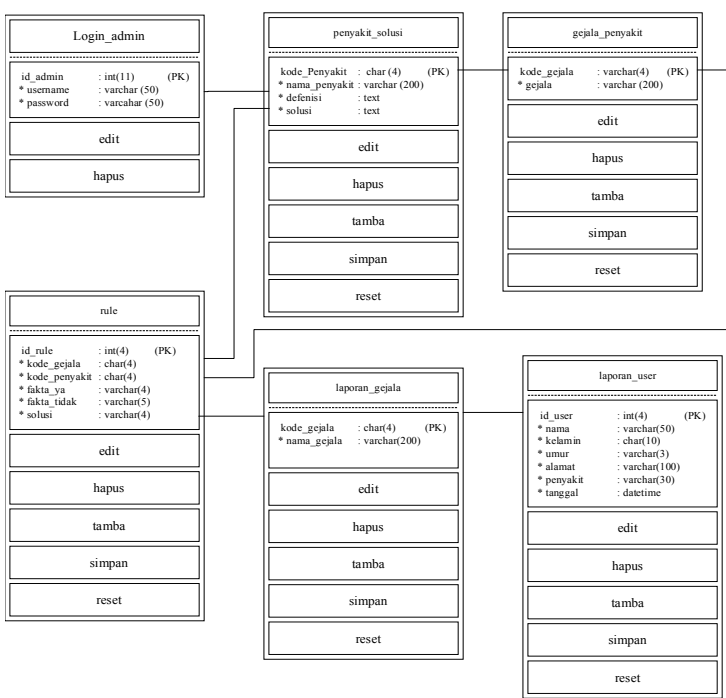

Gambar 7. Calss diagram

\section{Rancangan Stuktur Tabel Database}

Tabel 1. Tabel Admin

\begin{tabular}{|l|l|c|l|}
\hline Nama_Field & $\begin{array}{l}\text { Type_Da } \\
\text { ta }\end{array}$ & $\begin{array}{l}\text { Ukura } \\
\mathrm{n}\end{array}$ & $\begin{array}{l}\text { Keteranga } \\
\mathrm{n}\end{array}$ \\
\hline ID_Admin & Varchar & 12 & Id_Admin \\
\hline Username & Varchar & 50 & $\begin{array}{l}\text { Nama } \\
\text { Admin }\end{array}$ \\
\hline Password & Varchar & 50 & Password \\
\hline
\end{tabular}

Tabel 2. Tabel Gejala

\begin{tabular}{|l|l|c|l|}
\hline Nama_Field & $\begin{array}{l}\text { Type_Da } \\
\text { ta }\end{array}$ & $\begin{array}{c}\text { Ukura } \\
\mathrm{n}\end{array}$ & $\begin{array}{l}\text { Keteranga } \\
\mathrm{n}\end{array}$ \\
\hline Kd_Gejala & Varchar & 4 & $\begin{array}{l}\text { Kd_Gejal } \\
\mathrm{a}\end{array}$ \\
\hline Gejala & Varchar & 200 & Gejala \\
\hline
\end{tabular}

Tabel 3. Tabel Penyakit

\begin{tabular}{|l|l|c|l|}
\hline Nama_Field & $\begin{array}{l}\text { Type_Dat } \\
\mathrm{a}\end{array}$ & $\begin{array}{c}\text { Ukura } \\
\mathrm{n}\end{array}$ & $\begin{array}{l}\text { Keteranga } \\
\mathrm{n}\end{array}$ \\
\hline Kd_Penyakit & Char & 4 & $\begin{array}{l}\text { Kd_Penya } \\
\text { kit }\end{array}$ \\
\hline $\begin{array}{l}\text { Nama_Penya } \\
\text { kit }\end{array}$ & Varchar & 200 & Penyakit \\
\hline Devenisi & Text & - & Devenisi \\
\hline Solusi & Text & - & Solusi \\
\hline
\end{tabular}

Tabel 4. Tabel Rule

\begin{tabular}{|l|l|c|l|}
\hline Nama_Field & $\begin{array}{l}\text { Type_Dat } \\
\mathrm{a}\end{array}$ & $\begin{array}{c}\text { Ukura } \\
\mathrm{n}\end{array}$ & $\begin{array}{l}\text { Keteranga } \\
\mathrm{n}\end{array}$ \\
\hline Kd_Rule & Int & 4 & Kd_Rule \\
\hline Kd_Gejala & Char & 4 & $\begin{array}{l}\text { Kd_Penya } \\
\text { kit }\end{array}$ \\
\hline Kd_Penyakit & Char & 4 & Kd_Gejala \\
\hline Fakta_ya & Varchar & 4 & Fakta_ya \\
\hline Fakta_TIdak & Varchar & 5 & $\begin{array}{l}\text { Fakta_Tida } \\
\text { k }\end{array}$ \\
\hline Solusi & Varchar & 4 & Solusi \\
\hline
\end{tabular}

Tabel 5. Tabel Tmp Analisis

\begin{tabular}{|l|l|c|l|}
\hline Nama_Field & $\begin{array}{l}\text { Type_Da } \\
\text { ta }\end{array}$ & $\begin{array}{c}\text { Ukura } \\
\mathrm{n}\end{array}$ & $\begin{array}{l}\text { Keteranga } \\
\mathrm{n}\end{array}$ \\
\hline Noip & Varchar & 30 & Noip \\
\hline $\begin{array}{l}\text { Kd_Penyaki } \\
\mathrm{t}\end{array}$ & Char & 4 & Penyakit \\
\hline Kd_Gejala & Char & 4 & Gejala \\
\hline
\end{tabular}

Tabel 6. Tabel Tmp Penyakit

\begin{tabular}{|l|l|c|l|}
\hline Nama_Field & $\begin{array}{l}\text { Type_Da } \\
\text { ta }\end{array}$ & $\begin{array}{c}\text { Ukura } \\
\mathrm{n}\end{array}$ & $\begin{array}{l}\text { Keteranga } \\
\mathrm{n}\end{array}$ \\
\hline Noip & Varchar & 30 & No_Hp \\
\hline $\begin{array}{l}\text { Kd_Penyaki } \\
\mathrm{t}\end{array}$ & Char & 4 & Penyakit \\
\hline
\end{tabular}




\begin{tabular}{|l|l|l|l|}
\hline Nilai & Double & - & Nilai \\
\hline
\end{tabular}

Tabel 7. Tabel User

\begin{tabular}{|l|l|c|l|}
\hline Nama_Field & $\begin{array}{l}\text { Type_Da } \\
\mathrm{ta}\end{array}$ & $\begin{array}{c}\text { Ukura } \\
\mathrm{n}\end{array}$ & $\begin{array}{l}\text { Keteranga } \\
\mathrm{n}\end{array}$ \\
\hline Id & Int & 4 & Id_User \\
\hline Nama & Varchar & 50 & Nama \\
\hline Kelamin & Char & 10 & Kelamin \\
\hline Umur & Varchar & 3 & Umur \\
\hline Alamat & Varchar & 100 & Alamat \\
\hline Noip & Varchar & 30 & No. Hp \\
\hline Tanggal & $\begin{array}{l}\text { Data_Ti } \\
\text { me }\end{array}$ & - & Tanggal \\
\hline
\end{tabular}

\section{Rancangan Menu Utama}

tampilan layout menu utama dari sistem yang muncul setelah penguna membuka aplikasi sistem pakar pendeteksi penyakit tamanan padi.

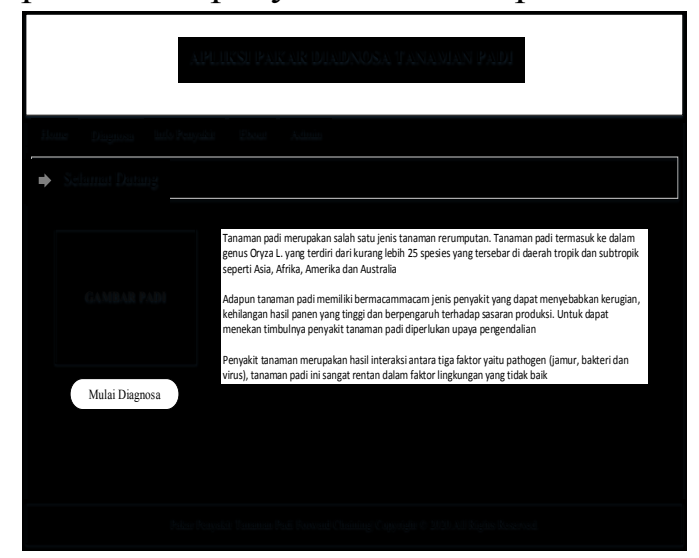

Gambar 8. Rancangan Menu Utama

\section{IMPLEMENTASI SISTEM}

Implementasi sistem merupakan hasil perancangan dan design dari aplikasi sistem pakar pendeteksi penyakit padi.

\section{Login Admin}

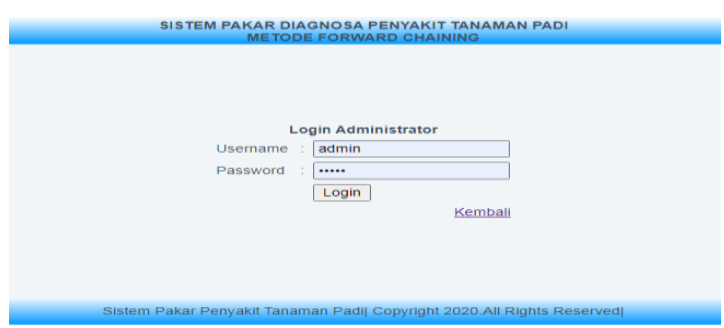

Gambar 9. Halman Login Admin

\section{Menu Utama (User)}

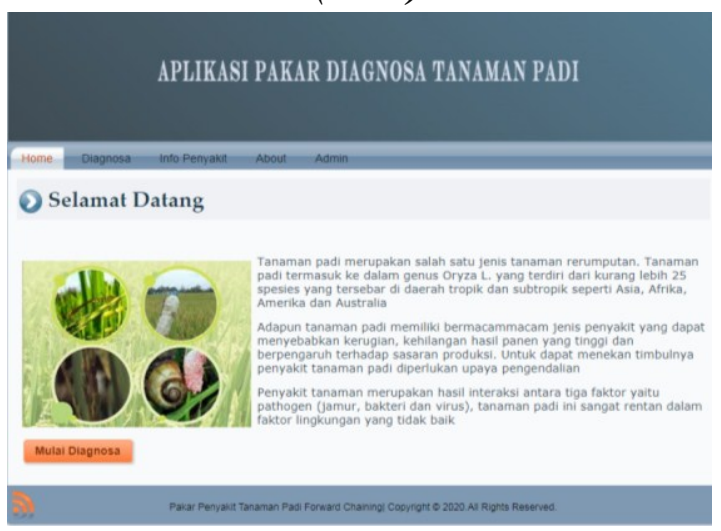

Gambar 10. Menu Utama

\section{Registrasi Diagnosa}

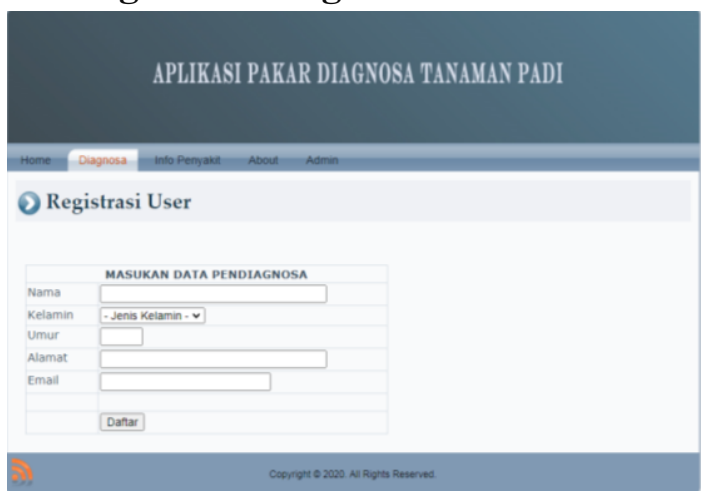

Gambar 11. Registrasi Diagnosa

\section{Diagnosa}




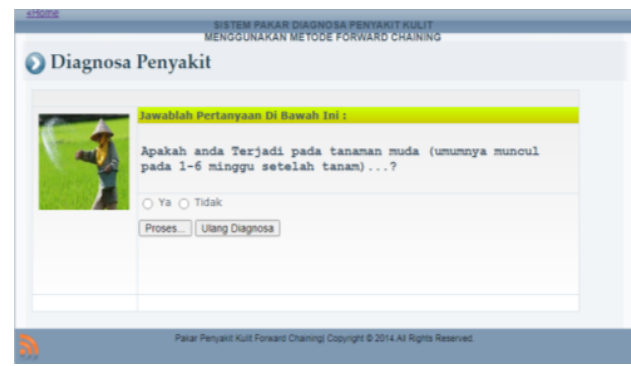

Gambar 12 Diagnosa Penyakit

\section{Hasil Diagnosa}

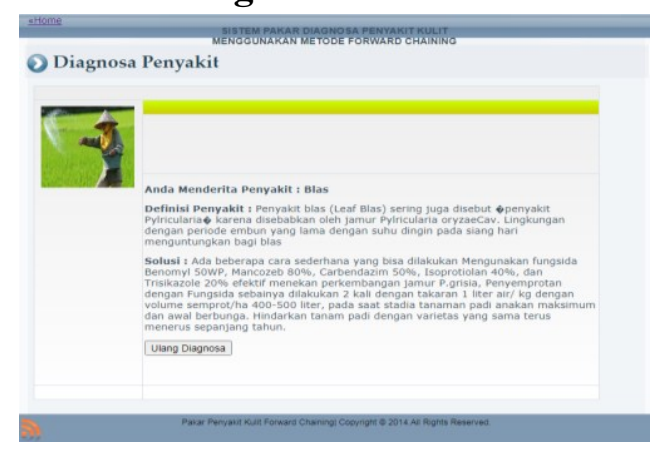

Gambar 13. Hasil Diagnosa

\section{Menu Utama (Admin)}

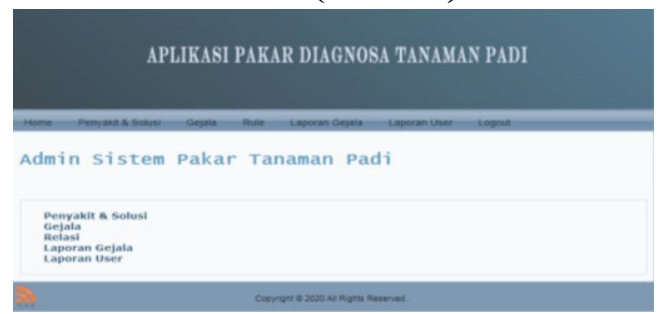

Gambar 14. Menu Utama Admin

\section{Menu Gejala}

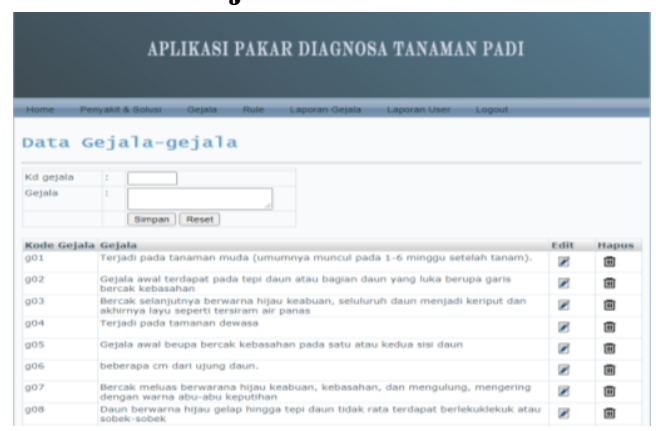

Gambar 15. Menu Gejala

\section{Menu Rule}

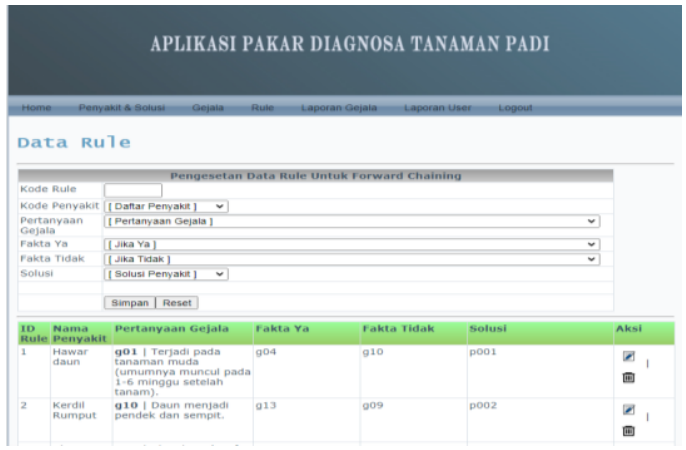

Gambar 16. Menu Rule

\section{PENGUJIAN SISTEM}

Pengujian yang akan digunakan untuk menguji sistem adalah mengunakan metode pengujian black box berfokus pada persyaratan fungsional perangkat lunak.

Tabel. 8 Pengujian Antar muka User

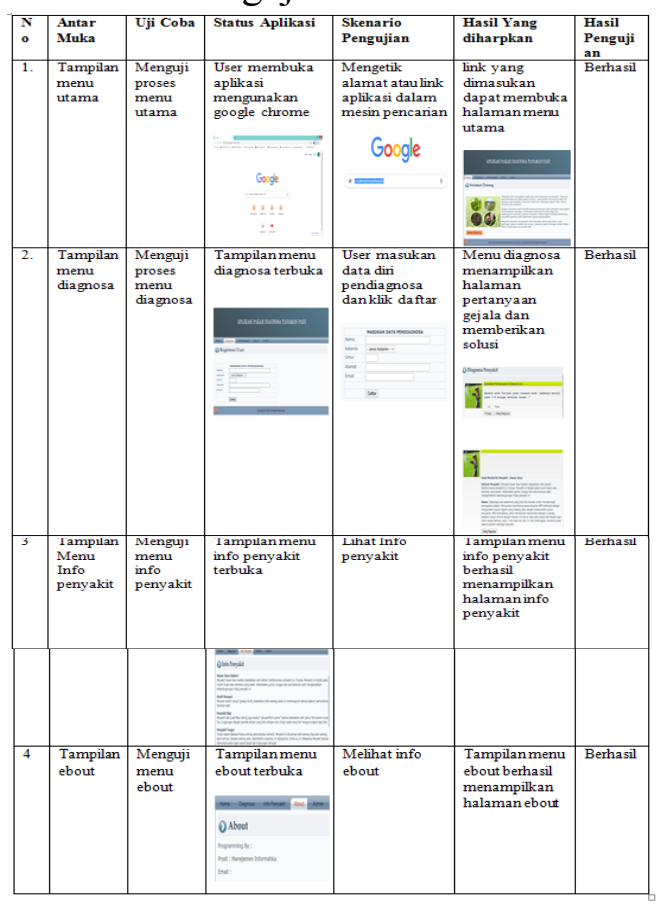

\section{KESIMPULAN}


Berdasarkan pembahasan yang telah dilakukan, maka dapat ditarik kesimpulan tentang Aplikasi Sistem Pakar Pendeteksi Penyakit Tanaman Padi Mengunakan Metode Forward Chaining dengan Gambar Berbasis Website di Desa Subaim Kecamatan Wasile sebagai berikut : 1) Aplikasi ini telah selesai dibangun sebagai solusi dari rumusan masalah yang diangakat yaitu membangun sistem pakar yang dapat digunakan untuk mengetahui hama dan penyakit pada tanaman padi berdasarkan gejala yang diberikan dan memberikan solusi penanganan terhadap hama dan penyakit yang menyerang tanaman padi. 2)Dengan adanya aplikasi ini dapat membantu petani mendiagnosa penyakit tanaman padi secara digital sehingga informasi maupun solusi yang dihasilkan sesuai dengan seseorang ahli pakar pertanian, tidak lagi harus mendatangi seorang ahli pakar kelokasi petani untuk mendiaknosa penyakit yang terserang pada tanaman padi.

\section{Saran}

Aplikasi sistem pakar berbasis website yang telah dibangun dalam penyelesaian tugas akhir ini masih jauh dari sempurna, untuk itu dirapkan agar dapat dikembangkan dimasa yang akan datang seiring dengan kemajuan teknologi formal, dan dalam perancangan mengenai aplikasi sistem pakar pendeteksi penyakit pada tanaman padi ini, diharapkan dapat memberikan penambahan data gejala dan penyakit tanaman padi, serta dalam prosesnya perlu ada pembedaan bagian yang diserang apakah (batang, daun, atau akar) sehingga gejala yang tampikan menjadi lebih spesifik.

\section{DAFTAR PUSTAKA}

Arief Dalam Noyat, A Ibrahim dan A Ambarita (2018) Sistem Informasi Pengaduan Pelanggaran air Berbasis Web Pada PDAM Kota Ternate Ijis Wirtama ISSN 25486438 Vol, 3 No, 1. April 2018, Hal. 12

Muhammad Ferawati, Karmila Djumati, syahril Hasan dan Ditje Lombo (2019), sistem Informasi akutansi potongan pajak PPh 21 mengunakan visual studio pada PT. Yushindo Yasa Perkasa Ternate, Ijis Wiratama, ISSN: 2548-6438 Vol. 4, No 2. Hal: 70, September 2019.

Muhammad Yusril Helmi Setyawan, Dinda Ayu Pratiwi (2019) membuat sistem informasi gadai online mengunakan kodeigniter serta kelola proses pemberitahuanya,https://books.goo gle.co.id/books?

Setiwan Anto Honggowibowo (2016). Sistem Pakar Diagnose Tanaman Padi Berbasis Web Dengan Forward dan Beckward Caining. Sekolah Tinggi Teknologi 
Adisutjipto, ISSN: 1693-6930, Vol.

7 No. 3 Desember 2016.

Sutojo, Edy Muliyanto dan Vincen Suhartono (2011), Kecerdasan Buatan, Andi Office, Yogyakarta. Yunaeti Anggraeni (2017). Pengantar sisteminformasi,https://books.googl e.co.id/books? 